\title{
IDENTIFY MISCONCEPTION ON REACTION RATE CONCEPT USING FOUR-TIER MULTIPLE CHOICE (4TMC) DIAGNOSTIC TEST INSTRUMENT
}

\author{
Ilham Pradana Putra Harahap ${ }^{1}$, Dian Novita ${ }^{* 2}$ \\ ${ }^{1,2}$ Chemistry Department, Faculty of Mathematic and Natural Science, State University of Surabaya \\ *Corresponding author: diannovita@unesa.ac.id
}

\begin{abstract}
The aims of this study to identify the profile of students' conceptions and misconceptions on the concept of reaction rate using a four-tier multiple choice diagnostic test instrument reported in the form of misconception profiles consisting of students' conceptions, students' misconceptions and the causes of misconceptions experienced by students. Based on the results of the study shown (1) the students' conception profile is as much as $78 \%$ understand the concept, $21 \%$ misconceptions and 1\% do not understand the concept, (2) the profile of student's misconceptions in each sub-material that misconceptions on sub-material of concentration 16\%, temperature 19\%, surface area $41 \%$ and catalyst $24 \%$ and as many as 1 student (3\%) including the high misconception category, 22 students (67\%) included in the medium misconception category and 10 students (30\%) were in the low misconception category. Students' misconceptions vary in different causes such as; associative thinking $59 \%$, preconceptions $25 \%$, incomplete resoning $13 \%$, humanistic thinking $2 \%$ and incorrect intuition $1 \%$.
\end{abstract}

Keywords: four-tier multiple choices, misconception, reaction rate

\section{INTRODUCTION}

According to Permendikbud No 20 Year 2016 regarding graduate competency standards, the dimensions of knowledge that must be possessed by SMA/MA/SMALB/Package $\mathrm{C}$ students are factual, conceptual, procedural, and metacognitive knowledge at the technical, specific, detailed, and complex levels. High school students required to have the ability of conceptual knowledge dimensions. One of the sciences related to conceptual knowledge is chemistry.

Chemistry is a branch of science that studies various things (composition, structure, properties, changes and accompanying energy) of a material developed by the scientific method and based on scientific attitude. Understanding the concepts in learning chemistry is very important because between one concept with another concept has a related relationship. The concept in chemistry is the important thing for students as a strong foundation to be able to do the next applicable learning. This is in line with Jean Piaget's thought (Suparno, 2001) which states that when students build their own understanding through the process of assimilation, namely the incorporation of old concepts with new concepts in cognitive structures, students often experience difficulties or even failures. This raises a variety of different understandings of a concept and the potential for misconception.

Misconceptions are wrong ideas or views about a concept of someone who has different from the scientific concepts according to the experts right consider. The wrong view of students is usually resistant and persistent (Ibrahim, 2012). Therefore, misconceptions must be detected from the beginning because misconceptions can interfere with students' understanding of new concepts to be learned later (Treagust, 2006).

The topic of reaction rates includes chemistry topic that are important and require high mastery of concept (Siswaningsih, et.all, 2014). Therefore, rate of reaction is one of the topics in chemistry that contains many concepts that interconnected with each other so that it has the potential to cause 
misconceptions in students. Based on Siswaningsih et al (2014), found as many as 35 students' misconceptions on the reaction of rate concept which includes collision theory and factors that influence the rate of reaction (concentration, temperature, surface area and catalyst). Based on the results of the pre-study of 36 students of class XI Science in one of the state high schools in Gresik, it was found that as many as $58 \%$ of them considered the reaction rate material to be difficult to understand. In addition, as many as $61 \%$ of students consider concentration factors to be material that is difficult to understand in terms of factors that influence the rate of reaction. Then what is considered difficult is the catalyst factor, temperature and surface area with a percentage of $56 \%, 47 \%$ and $33 \%$, respectively. In addition to students' assumptions that the reaction rate material is difficult, in this case also found students' misconceptions. Students were identified as having a misconception on the concept of a concentration factor of $14 \%$, on a temperature factor of $39 \%$, on a surface area factor of $40 \%$ and on a catalyst factor of $26 \%$. The existence of this misconception must certainly detected so that it can fixed immediately. Meanwhile, according to the results of an interview with one of the chemistry teachers at the school explained that so far the teacher only uses daily tests and oral questions to students to check students' understanding of concepts. Thus, the teacher never used a diagnostic test to detect the misconception.

One way to find out misconceptions in students is by diagnostic tests. Diagnostic test as a test can be used to determine the weaknesses and strengths of students (Depdiknas, 2007). Thus, the results of diagnostic tests used as a basis for providing follow-up in the form of appropriate treatment and in accordance with the weaknesses of students. The use of diagnostic tests at the beginning and at the end of learning can help teachers find students' misconceptions on the material being studied (Lin, 2004).

This four-tier multiple choice diagnostic test instrument is organized based on four levels of questions. The first level is a multiple choice question with four options and one key answer that students must choose. The second level is the level of confidence of students in choosing answers. The third level is the reason students answer questions, in the form of four reasons for option and one reason for the correct answer. The fourth level is the level of confidence of students in choosing reasons.

\section{METHOD}

The subjects in this study were 33 students of class XI Science 1 of SMAN 1 Driyorejo who had received reaction rate material and with heterogeneous ability levels. Students are given diagnostic tests to know the level of conception and misconception they experience. The answers of students are interpreted according to table 1 below.

Table 1. Interpretation of the Results of Students' Combination of Answers Using the FourTier Multiple Choice Diagnostic Test Instrument

\begin{tabular}{|c|c|c|c|c|}
\hline $\begin{array}{c}\text { The } \\
\text { answer }\end{array}$ & $\begin{array}{c}\text { Confid } \\
\text { ence } \\
\text { level of } \\
\text { answer }\end{array}$ & Reason & $\begin{array}{l}\text { Confid } \\
\text { ence } \\
\text { level of } \\
\text { reason }\end{array}$ & Criteria \\
\hline Right & High & Right & HIgh & $\begin{array}{c}\text { Understan } \\
\mathrm{d} \text { the } \\
\text { concept }\end{array}$ \\
\hline Right & Low & Wrong & High & \multirow{7}{*}{$\begin{array}{l}\text { Misconcep } \\
\text { tion }\end{array}$} \\
\hline Right & High & Wrong & High & \\
\hline Wrong & High & Right & Low & \\
\hline Wrong & High & Right & High & \\
\hline Wrong & High & Wrong & Low & \\
\hline Wrong & Low & Wrong & High & \\
\hline Wrong & High & Wrong & High & \\
\hline Right & Low & Right & Low & \multirow{8}{*}{$\begin{array}{l}\text { Not } \\
\text { understand } \\
\text { the concept }\end{array}$} \\
\hline Right & High & Right & Low & \\
\hline Right & Low & Right & High & \\
\hline Right & Low & Wrong & Low & \\
\hline Wrong & Low & Right & Low & \\
\hline Wrong & Low & Wrong & Low & \\
\hline Right & High & Wrong & Low & \\
\hline Right & Low & Right & High & \\
\hline
\end{tabular}

Answers that have been given by students in doing four-tier multiple choice diagnostic tests are interpreted as misconceptions where concepts are understood, conceptual or conceptual misconceptions.

The test results shown a basic in determine the conception level categories of students according to Table 1. Determination of the percentage of each of these categories can use the following equation 
1) Percentage of conception level categories for all students

Information:

$$
P=\frac{n x}{n s} \times 100 \%
$$

$\mathrm{P}$ : percentage of students' answers

$\mathrm{nx}$ : number of answers categorized as understanding concepts, not understanding concepts and misconceptions

ns: total number of answers

2) Percentage of conception level categories for each students

\section{Description:}

$$
P=\frac{n x}{n s} \times 100 \%
$$

P: percentage of students' answers

$n x$ : number of answers categorized as understanding concepts, not understanding concepts and misconceptions

ns: total number of answers

From the calculation of the percentage of misconceptions, the sample of students further categorize into 3 levels of misconceptions. The criteria for each of misconception level categories is determined by Arikunto (2005) is as follows:

- High misconception level category

Information:

$$
(\mathrm{X}) \geq(\mathrm{Mi}+\mathrm{SD})
$$

$$
\begin{array}{ll}
\mathrm{X} & \text { : percentage of misconception (\%) } \\
\mathrm{Mi} & \text { : ideal mean } \\
\mathrm{SD} & \text { : standard deviation }
\end{array}
$$

- Medium misconception level category

Information:

$$
(\mathrm{Mi}-\mathrm{SD}) \leq(\mathrm{X})<(\mathrm{Mi}+\mathrm{SD})
$$

$\mathrm{X}$ : percentage of misconception (\%)

$\mathrm{Mi}$ : ideal mean

SD : standard deviation

- Low misconception level category

Information:

$$
(\mathrm{X})<(\mathrm{Mi}-\mathrm{SD})
$$

$\mathrm{X}$ : percentage of misconception (\%)

$\mathrm{Mi}$ : ideal mean

SD : standard deviation

As for calculating the ideal mean and standard deviation, the equation is used

$$
\begin{aligned}
& \left.M i=\frac{1}{2} \text { (highest score }+ \text { lowest score }\right) \\
& S D=\frac{1}{3} \text { (highest score }- \text { lowest score) }
\end{aligned}
$$

\section{RESULT AND DISCUSSION}

\section{Student Conception Profile Class XI Science 1}

Based on the results of trials that have been done, the data result in the form of a combination of answers from each student. The combination of answers consists of 4 components, namely: (1) answers, (2) confidence level of answer, (3) reasons and (4) confidence level of reason. Furthermore, each combination of answers interpreted includes: (1) Understanding Concepts (UC), (2) Misconceptions (MC) and (3) Not Understanding Concepts (NUC). According to the data results on 33 students of class XI Science 1, the profile of students' conception in general shown in Figure 1.

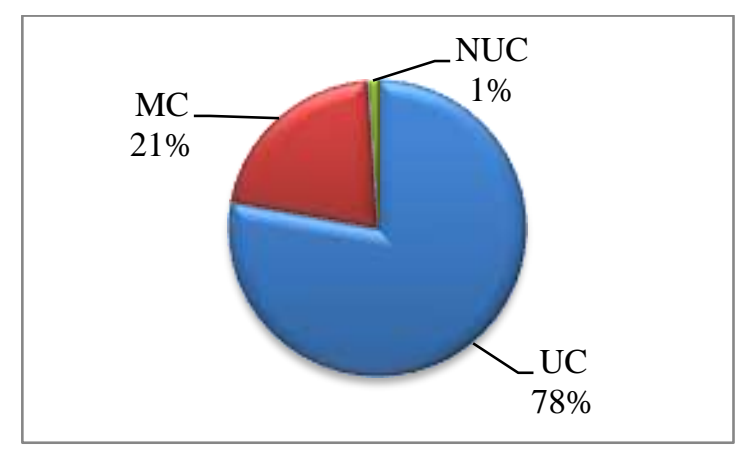

Figure 1. Student Conception Profile Class XI Science 1 on the Reaction Rate Concept

Based on Figure 1 above, the largest percentage of students' conceptions of XI Science 1 is Understanding Concepts (UC), which is $78 \%$. Next, the percentage order from the biggest to smallest is Misconception (MC) of 21\% and Concept Understanding (NUC) of $1 \%$ respectively. Most students categorized in the Understanding Concept (UC) category which has both correct answers and reasons also confident of the answers and reasons given. This is in line with the result of the study of Pajaindo et al [10], that most high school students of grade XI Science have sufficient understanding of the concept reaction rate. As many as $21 \%$ of students experience Misconceptions (MC) on the concept of this reaction rate in which students believe the answers and reasons are wrong. Meanwhile, only a small proportion of students who do not understand the concept (NUC) where students are not sure of the answers and reasons given. 


\section{Profile of Misconceptions for Each Class XI Science 1 Student}

Students of XI Science 1 mostly experience misconceptions on the whole submaterial reaction rate, namely concentration, temperature, surface area and catalyst. Percentage of students' misconceptions per sub material is explained in Figure 2 below.

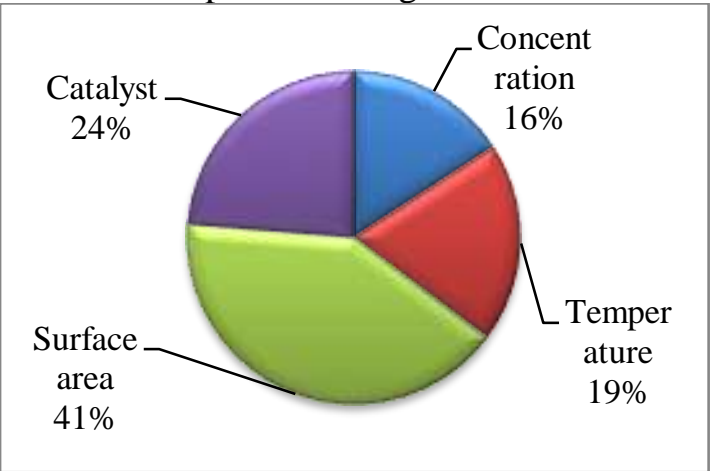

Figure 2. Percentage of Students' Misconceptions for each Sub Material

According to Figure 2, the largest percentage of misconceptions of students in XI Science 1 is in the sub-surface area of $41 \%$. While the smallest percentage of misconception is the sub-material concentration of $16 \%$. While the temperature and catalyst sub material students of class XI Science 1 experienced misconceptions of $19 \%$ and $24 \%$.

Students' conception categorized according to the percentage value of their misconceptions ranging from high misconceptions, moderate misconceptions and low misconceptions as in Table 2 below.

Table 2. Recapitulation of Percentage of Conception of Students Based on Sequence of Misconceptions and their Categories

\begin{tabular}{cccccc}
\hline \multirow{2}{*}{$\begin{array}{c}\text { N } \\
\text { o }\end{array}$} & $\begin{array}{c}\text { Student } \\
\text { 's name }\end{array}$ & \multicolumn{2}{c}{$\begin{array}{c}\text { Conception } \\
\text { Percentage (\%) }\end{array}$} & $\begin{array}{c}\text { Misconcepti } \\
\text { on Category }\end{array}$ \\
\cline { 3 - 5 } & & UC & MC & NUC & \\
\hline 30 & TIR & 25 & 60 & 15 & High \\
\hline 13 & LEO & 60 & 40 & 0 & Medium \\
\hline 25 & SET & 65 & 35 & 0 & Medium \\
\hline 27 & STE & 55 & 35 & 10 & Medium \\
\hline 28 & SUR & 60 & 35 & 5 & Medium \\
\hline
\end{tabular}

\begin{tabular}{|c|c|c|c|c|c|}
\hline \multirow{2}{*}{$\begin{array}{c}\mathrm{N} \\
\mathrm{o}\end{array}$} & \multirow{2}{*}{$\begin{array}{l}\text { Student } \\
\text { 's name }\end{array}$} & \multicolumn{3}{|c|}{$\begin{array}{c}\text { Conception } \\
\text { Percentage }(\%)\end{array}$} & \multirow{2}{*}{$\begin{array}{l}\text { Misconcepti } \\
\text { on Category }\end{array}$} \\
\hline & & UC & $\mathrm{MC}$ & NUC & \\
\hline 1 & $\mathrm{ABD}$ & 70 & 30 & 0 & Medium \\
\hline 6 & BAY & 70 & 30 & 0 & Medium \\
\hline 11 & FAD & 65 & 30 & 5 & Medium \\
\hline 19 & PUT & 70 & 30 & 0 & Medium \\
\hline 20 & RAH & 70 & 30 & 0 & Medium \\
\hline 29 & THO & 70 & 30 & 0 & Medium \\
\hline 4 & ALF & 75 & 25 & 0 & Medium \\
\hline 5 & ANA & 80 & 20 & 0 & Medium \\
\hline 12 & KHA & 80 & 20 & 0 & Medium \\
\hline 14 & MAZ & 80 & 20 & 0 & Medium \\
\hline 23 & RIK & 80 & 20 & 0 & Medium \\
\hline 33 & ZEF & 80 & 20 & 0 & Medium \\
\hline 15 & MIA & 85 & 15 & 0 & Medium \\
\hline 16 & ALI & 85 & 15 & 0 & Medium \\
\hline 21 & RAM & 85 & 15 & 0 & Medium \\
\hline 22 & RAT & 85 & 15 & 0 & Medium \\
\hline 24 & SEP & 85 & 15 & 0 & Medium \\
\hline 31 & YUS & 85 & 15 & 0 & Medium \\
\hline 2 & ABR & 90 & 10 & 0 & Low \\
\hline 3 & $\mathrm{ADH}$ & 90 & 10 & 0 & Low \\
\hline 7 & BEL & 90 & 10 & 0 & Low \\
\hline 8 & DEL & 90 & 10 & 0 & Low \\
\hline 9 & EKA & 90 & 10 & 0 & Low \\
\hline 17 & NAD & 90 & 10 & 0 & Low \\
\hline 18 & NUR & 90 & 10 & 0 & Low \\
\hline 26 & SIS & 90 & 10 & 0 & Low \\
\hline 32 & YUV & 90 & 10 & 0 & Low \\
\hline 10 & EMA & 95 & 5 & 0 & Low \\
\hline
\end{tabular}

Based on the recapitulation of misconception categories, the pie chart shown on the Figure 3 below. 


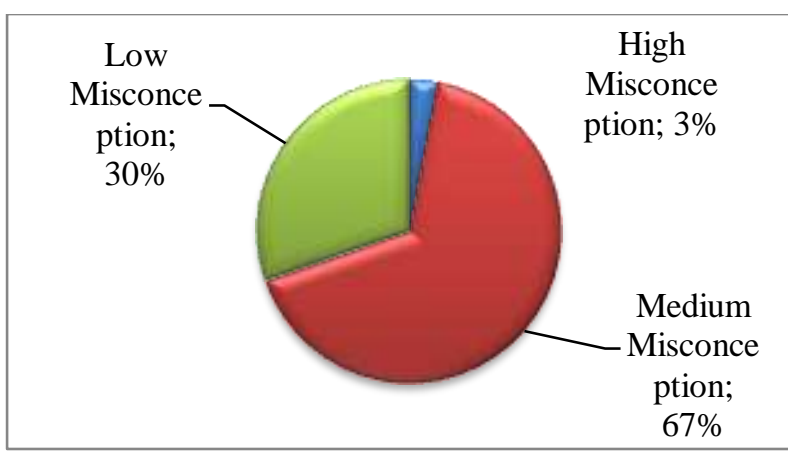

Figure 3. Diagram of percentage of students' misconceptions in class XI Science 1

Based on the diagram, only $3 \%$ or 1 students categorized as high misconceptions, $67 \%$ or 22 students categorized as moderate misconceptions and the remaining $30 \%$ or 10 students classified as low misconceptions.

\section{Causes of Class XI Science 1 Student Misconceptions}

The causes of students' misconceptions vary several factors, such as the teacher, learning media, and also from the students themselves. The specific causes of students' misconception which originating from themselves can be vary such as: (1) Associative Thinking (AT), (2) Humanistic Thinking (HT), (3) Preconception (P), (4) Incomplete reasoning (R) and (5) Incorrect intuition (I). Overall, the distribution of causes of misconceptions of XI Science 1 students shown in Figure 4 below.

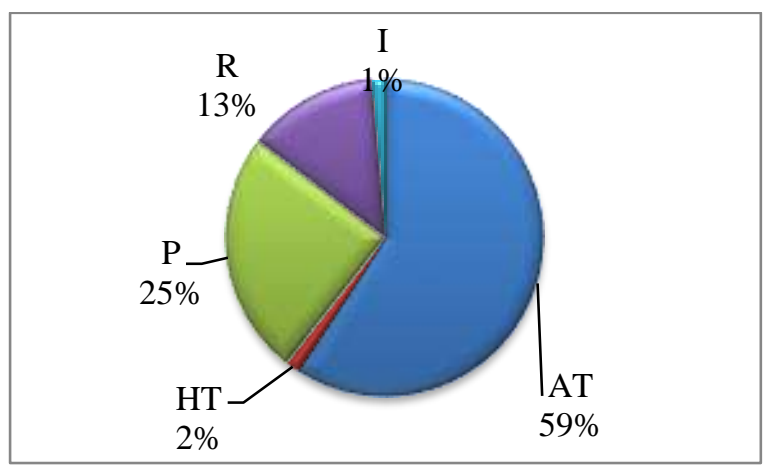

Figure 4. Causes of class XI Science 1 students' misconceptions on the concept of Reaction Rate

Based on Figure 4, the biggest cause of misconception of students comes from associative thinking that is equal to $59 \%$. Associative thinking is a thought that considers a concept the same as another concept. Students often associate one concept with another concept that actually gives rise to misconceptions. This way of thinking can occur because of the similarity of terms and errors in understanding the relationship between concepts.

\section{CLOSING}

\section{Conclusion}

Students' misconception profiles can be known using instruments that have been developed.

1. The conception profile of students class XI Science 1 on the concept of reaction rate is $78 \%$ understood the concept, $21 \%$ misconceptions and $1 \%$ did not understand the concept.

2. Profile of misconceptions of students of XI Science 1 for each sub-material, which are misconceptions on sub-material concentration of $16 \%$, temperature $19 \%$, surface area $41 \%$ and catalyst $24 \%$. A total of 1 students (3\%) included in the high misconception category, 22 students $(67 \%)$ were in the moderate misconception category and 10 students (30\%) were in the low misconception category.

3. The biggest cause of misconception of students is due to associative thinking as $59 \%$. Then preconception $25 \%$, incomplete reasoning $13 \%$. The causes of misconceptions from humanistic thinking and incorrect intuition are $2 \%$ and $1 \%$, respectively.

\section{Suggestion}

The teacher in the learning process has to emphasizes on sub-surface area material to minimize the potential for misconceptions experienced by students.

\section{REFERENCES}

[1]Permendikbud No 20 Tahun 2016 Tentang Standar Kompetensi Lulusan Pendidikan Dasar dan Menengah

[2] Suparno, Paul. 2001. Teori Perkembangan Kognitif Jean Piaget. Yogyakarta: Kanisius.

[3] Ibrahim, Muslimin. 2012. Seri Pembelajaran Inovatif: Konsep, Miskonsepsi dan Cara Pembelajarannya. Surabaya: Unesa University Press.

[4] Treagust, D. 2006. "Diagnostic Assessment in Science as a Means to Improving Teaching, Learning and Retention". In 
UniServe Science Assessment Symposium, Sep 28, 2006, Sydney, NSW: UniServe Science, The University of Sydney

[5] Siswaningsih, W., Anisa, N., Komalasari, N E., \& Indah R. 2014. Pengembangan Tes Diagnostik Two-Tier untuk Mengidentifikasi Miskonsepsi pada Materi Kimia Peserta didik SMA. Jurnal Pengajaran MIPA, 19(1), 117-127.

[6]Depdiknas. 2007. Tes Diagnostik, Direktorat Pembinaan Sekolah Menengah Pertama. Jakarta: Direktorat Jenderal Manajemen Pendidikan Dasar dan Menengah.

[7]Lin, S. 2004. Development and Application of a Two-Tier Diagnostic Test for High School Students' Understanding of
Sowering Plant Growth and Development. International Journal of Science and Mathematics, 2(2), 175-199.

[8]Fariyani, Q., Rusilowati, A., \& Sugianto. 2015. Pengembangan Four-Tier Diagnostic Test untuk Mengungkap Miskonsepsi Fisika Peserta didik SMA Kelas X. Journal of Innovative Science Education, 4(2), 41-49

[9]Arikunto Suharsimi. 2005. Dasar-dasar Evaluasi Pendidikan, Jakarta: Bumi Aksara.

[10] Pajaindo, O P., Prayitno, \& Fajaroh, F. 2013. Menggali Pemahaman Siswa SMA pada Konsep Laju Reaksi dengan Menggunakan Instrumen Diagnostik TwoTier. Jurnal Pendidikan Kimia, 2(2), 1-6 